\title{
The Effect of a Manager's Emotional Intelligence on Employees' Work Outcomes in the Insurance Industry in Jordan
}

\author{
Taghrid S. Suifan ${ }^{1}$, Ayman Bahjat Abdallah ${ }^{1} \&$ Rateb J. Sweis ${ }^{1}$ \\ ${ }^{1}$ Department of Business Management, Faculty of Business, The University of Jordan, Jordan \\ Correspondence: Taghrid S. Suifan, Department of Business Management, Faculty of Business, The University \\ of Jordan, Amman, Jordan. Tel: 962-795-546833. E-mail: t.suifan@ju.edu.jo
}

Received: June 28, 2015

Accepted: July 24, 2015

Online Published: August 25, 2015

doi:10.5539/ibr.v8n9p67

URL: http://dx.doi.org/10.5539/ibr.v8n9p67

\begin{abstract}
This study investigates the effect of emotional intelligence on employees' work outcomes of job satisfaction, organizational commitment, and customer service behavior in Jordan. Emotional intelligence was measured using Emotional Competence Inventory (ECI) model. Data were collected from 193 respondents in the insurance industry. Linear regressions were used to test the hypothesized effects. The results indicate that all emotional intelligence dimensions of self-awareness, self-management, social awareness, and relationship management positively and significantly affect all employees' work outcomes. Additionally, the results show that emotional intelligence overall scale positively and significantly affects employees' work outcomes.
\end{abstract}

Keywords: emotional intelligence, employees' work outcomes, service industry, Jordan, empirical study

\section{Introduction}

\subsection{Background and Significance of the Problem}

The concept of emotional intelligence (also referred to herein as 'EI') has become increasingly popular in today's competitive world. EI has become the buzzword for over two decades and organizations are turning to EI as a secret ingredient to harvest positive attitudes and behaviors from their employees. Scholars tend to regard EI as a key contributor to achieving employee commitment, customer satisfaction as well as financial rewards. Therefore, intelligence is no longer viewed as uni-dimensional, focusing only on cognitive abilities but rather intelligence has been realized for what it truly is; a multi-dimensional construct that includes other types of intelligence such as social, cultural and emotional intelligence. Goleman (1995, 1998), Sternberg (1996) and Martin (1998) claim that despite the significance of intellectual intelligence, emotional intelligence is even more important; with some boldly asserting that 80 percent of work success is attributed to EI.

EI origins can be located at the concept of social intelligence (Trivellas, 2013) and is somewhat related to the concept of cultural intelligence 'CQ' which is defined as an individual's capability to behave and manage effectively in culturally diverse settings (Early \& Ang, 2003). In his theory of multiple intelligences, Gardner (1983) lists interpersonal and intrapersonal intelligences that are closely related to social intelligence, and though Gardner did not explicitly use the term EI, his ideas of interpersonal and intrapersonal intelligences paved the way for the disclosure of EI.

Despite the fact that the term EI was formally first introduced by psychologists Salovey and Mayer (1990), the prevalence of the concept should be attributed to Daniel Goleman in his best-seller 'Emotional Intelligence'. His work challenged the legitimacy of viewing intelligence as merely cognitive. Instead, he shed light on the value of emotional intelligence as an essential ingredient in the success of organizations with his well-known saying: "When people feel good, they work at their best" (Goleman et al., 2002). With this, Goleman sparked controversy in the fledgling field of psychology, social sciences and organizational behavior. Some even argue that "there is perhaps no construct in the social sciences that has produced more controversy in recent years" (McCleskey, 2014).

Following the introduction of EI, attempts to conceptualize the term were consumed by many researchers. Though, consensus among research studies regarding a crystal clear definition of EI has not yet been reached, nonetheless, it can be thought of as a set of abilities that enable a person to generate, recognize, express, understand, and evaluate its own and others' emotions in order to guide thinking and action (VanSickle, 2004). 
Numerous models and assessment instruments have been developed to measure EI and investigate its correlations with work-related behaviors, attitudes and outcomes. Perhaps, one of the most popular models is the Emotional Competency Inventory (ECI) developed by Boyatzis et al. (2000) by refining Goleman's (1998) emotional intelligence model from five dimensions (self-awareness, self-regulation, motivation, empathy and social skills) down to four (self-awareness, self-management, social awareness and relationship management), to capture the full scope of emotional competencies (Lam \& O'Higgins, 2012). Based on the previous argument, the ECI was, therefore, adopted in this study.

In spite of the widespread popularity of EI in the literature, many recent studies call out for the need for further research examining the impact of EI (such as Brunetto, 2012). This study reaches out to answer these callings. In addition, it can be seen that many studies related to EI have taken place in few developing countries (Alawneh, 2013). Again, this study comes into play seeking to assess the effect of a manager's emotional intelligence (EI) on employees' work outcomes of job satisfaction, organizational commitment, and customer service behavior in the insurance industry in Jordan.

Though EI is significant across all sectors and industries, perhaps it is more dominant in the service sector where EI flourishes with such frequent service encounters. Since Jordan is a service-oriented country with the service sector representing 67 percent of the country's gross domestic product 'GDP' where service companies comprise over 70 percent of all listed companies in the stock exchanges (Heizer et al., 2013), Jordan could be considered an ideal developing country for investigating EI.

\subsection{Research Questions}

The purpose of this research is to assess the effect of a manager's emotional intelligence (EI) on employees' work outcomes of job satisfaction, organizational commitment, and customer service behavior in the insurance industry in Jordan, more specifically to find answers to the following questions:

1). Does the manager's emotional intelligence affect the employee's overall job satisfaction and if it does, what are the emotional intelligence dimensions that affect the employee's job satisfaction the most?

2). Does the manager's emotional intelligence affect the employee's organizational commitment and if it does, what are the emotional intelligence dimensions that affect the employee's organizational commitment the most?

3). Does the manager's emotional intelligence affect the employee's customer service behavior and if it does, what are the emotional intelligence dimensions that affect the employee's customer service behavior the most?

\section{Literature Review}

\subsection{Emotional Intelligence}

Emotions, over time, have captured the attention of researchers from various disciplines; psychology (Carmeli et al., 2009); sociology (Tenhouten,1996); science (Barbalet, 2004); conflict resolution (Mingkai \& Oluremi, 2012) and management (Renae \& Michelle, 2013 ). This cross-disciplinary interest is such a complex concept perhaps due to the fact that emotions have direct influence on our actions (Stanley \& Burrows, 2005).

Emotions are indeed a powerful motivator for future behavior (LeDoux, 1998); nevertheless, emotions were perceived by some, at one point, as having a negative interference with cognitive activity displacing rational thinking (Fineman, 2000). Despite this outlook, many have come to view emotions in a more positive manner and argue that emotions are, in fact, essential for rational thinking (such as De Sousa, 1987; Damasio, 1994). This mentality has paved the way for various disciplines to materialize, and among these is the well-renowned discipline of Emotional Intelligence. Salovey and Mayer (1990) argued that there is a set of three conceptually related mental processes; appraising and expressing emotions in the self and others; regulating emotion in the self and others; and using emotions in adaptive ways involving emotional information.

Though Salovey and Mayer (1990) are the first to propose EI as a single concept, it is debated that EI first originated from the concept of Social Intelligence that was first defined by Thorndike back in 1920 as the ability to understand and manage others to act wisely in human relations (Boyatzis \& Sala, 2004; Maini et al., 2012; Lam \& O'Higgins, 2012). The concept gained popularity when Gardner (1983) proposed a theory of multiple intelligences which, among others, included two distinct elements described as 'interpersonal' and 'intrapersonal' intelligence. Interpersonal intelligence was described as the ability to understand and discern the feelings and intentions of others; whereas intrapersonal related to the ability to understand one's own feeling and motivation. Arguments continued to advocate EI as one of the key kinds of intelligences throughout the years. Notably, Both Gardner's (1983) multi-intelligence work as well as Steiner's (1984) work on emotional literacy are presumed to be the building blocks of what Salovey and Mayer (1990) first termed as Emotional Intelligence. 
There seems to be a consensus among many researches (such as Kerr et al., 2006; Catwright \& Pappas, 2008; Brunetto, 2012; Adeoyo \& Torubelli, 2011) regarding the introduction of the EI term. Salovey and Mayer (1990) first used the expression "Emotional Intelligence" and described it in terms of the subset of social intelligence that includes the ability to monitor one's own as well as others' emotions, to discriminate among the positive and negative effects of emotion and to use emotional information to guide one's thinking and actions. Other conceptualizations have used similar labels such as "Practical Intelligence" and "Successful Intelligence" (Sternberg, 1996). Mayer and Salovey (1990) then refined their original definition and framework several times which eventually led them to describe EI in terms of four domains: self-awareness, managing emotions, motivating one self and handling relationship. Thus, this implies that the previous conviction of the two mental processes of thinking and feeling being distinct is no longer held. Instead, both cognition and emotions actually work simultaneously (Kerr et al., 2006). More recent views also assert that emotional intelligence should be differentiated from other intelligence as it deals with the management of emotions and therefore specifically describes the complex process that links emotion and cognition (Brunetto, 2012).

Goleman (1998) defined emotional competency as a learned capability based on emotional intelligence that results in outstanding performance at work. In other words, a competency is an underlying characteristic of the person that leads to or causes effective or superior performance (Boyatzis, 1982). Combining both contributions of Boyatzis (1982) and Goleman (1998), an emotional intelligence competency is an ability to recognize, understand, and use emotional information about oneself or others that leads to or causes effective or superior performance.

Many recent attempts have been made by scholars in the field to describe EI in modern terms. For example, emotional intelligence was defined by Adeoye and Emeke (2010) as the ability to recognize one's own feeling and those of others for motivating self as well as one's relationship with others. This is more or less similar to Golaman's original definition increasing the original definition's validity.

Understandably, the new unexplored blue ocean of EI ignited a growing body of research regarding its construct, antecedents, importance for successful leadership as well as correlations with work-related attitudes and behaviors. In addition, the field of EI research has become overwhelmed with a flood of different tests all purporting to be effective assessments of an individual's EI. Underlying this research interest is the view that people with high emotional intelligence competencies are more likely than less emotionally intelligent people to gain success in the workplace (Carmeli, 2003).

\subsubsection{Emotional Intelligence Dimensions}

Ample EI models have been developed ever since the emergence of EI as a standalone construct. These include amongst other, the multifactor emotional intelligence scale 'MEIS' (Mayer et al., 1999), the emotional competency inventory 'ECI ' (Goleman, 1998), the emotion-quotient inventory 'EQ-I' (Bar-On, 1997), the emotional intelligence quotient 'EIQ' (Dulewicz \& Higgs, 2000), the self-report emotional intelligence test 'SREIT' (Schutte et al., 1998) and the workgroup emotional intelligence profile 'WEIP' (Jordan et al., 2002).

Recent developments of the EI models involve the segregation of current models into mixed and ability categories (Caruso et al., 2002; Day \& Carroll, 2004; Hedlund \& Sternberg, 2000). Ability models of EI are the ones that exclusively focus on cognitive aptitudes, referring to EI as a form of intelligence reflecting the ability to process emotional information (Caruso et al., 2002; Day \& Carroll, 2004). On the other hand, mixed models are the ones that incorporate a diverse range of abilities, behaviors, and personality traits within their EI framework (Mayer et al., 2000).

The Emotional Competence Inventory 'ECI' is one of the most favored and prevalent models out there. Comprised of 72 items, ECI is primarily used with the Boyatzis-Goleman mixed model of EI and is both a self-report and multi-rater instrument of how individuals express their handling of emotions in life and work settings (Boyatzis \& Sala, 2004). The self-report is an invitation to measure how an individual manifests some EI competencies and the multi-rater includes observers from the individual's professional context; managers, subordinates, peers and customers.

Based on the above review, we have adopted in this study the ECI model which was developed by Boyatzis et al. (2000) and consists of four dimensions: self-awareness, self-management, social awareness, and relationship management to measure EI.

\subsubsection{Self-Awareness}

Self-awareness, or in other words, emotional knowledge is concerned with understanding both the determinants and consequences of moods and emotions, and how they evolve and change over time (George, 2000). 
Variance in peoples' self- awareness explains their differences in understanding of how different situations, events, other people, and other stimuli generate emotions (George, 2000). Thus, self-awareness is defined as knowing one's emotions, recognizing a feeling as it happens and is the keystone of emotional intelligence (Goleman, 1998).

The concept of self-awareness is so important that it is seen as the prerequisite of the other dimensions and that it is the dimension that initiates all the relationships (Sunindijo \& Hadikusumo, 2013). Moreover, Goleman (1995) and Bar-On (1997) identified self-awareness as the most important dimension of emotional intelligence.

This study views the self-Awareness dimension comprising of three competencies:

Emotional Awareness: Recognizing one's emotions and their effects.

Accurate Self-Assessment: Knowing one's strengths and limits.

Self-Confidence: A strong sense of one's self-worth and capabilities.

\subsubsection{Self-Management}

Emotional intelligence captures individual differences to the extent in which one is able to successfully manage moods and emotions. Management of one's own moods and emotions-referred to by many as self-control-relies on knowledge and consideration of the determinants, appropriateness, and malleability of moods and emotions (Mayer et al., 1999). The knowledge of one's internal states of emotion allows self-control and leads to empathy in others. Further, self-managing of one's emotions can help foster positive moods and abandon anger, anxiety and gloom (Goleman, 1996). In addition, self-management, as proven at the neurological level, is the predictor of social awareness and relationship management (Sunindijo \& Hadikusumo, 2013), which will be discussed next.

In conclusion, self-management refers to managing ones' internal states, impulses, and resources and contains the following six competencies:

Emotional Self-Control: Keeping disruptive emotions and impulses in check.

Transparency: Maintaining integrity, acting congruently with one's values.

Adaptability: Flexibility in handling change.

Achievement: Striving to improve or meeting a standard of excellence; Initiative: Readiness to act on opportunities.

Optimism: Persistence in pursuing goals despite obstacles and setbacks.

\subsubsection{Social Awareness}

Social awareness is a fundamental emotional competency and determines how individuals handle relationships (Goleman, 1998) and is defined by Goleman (1995) as the ability to recognize emotions in others, or the ability to know how another feels.

The Social Awareness cluster is seen to consist of three competencies:

Empathy: Empathy is the people's foundation skill (Goleman, 1995) and refers to the awareness of other's feelings, needs and concern.

Organizational Awareness: This competency involves reading a group's emotional currents and power relationships.

Service Orientation: Finally, this competency refers to anticipating, recognizing, and meeting customers' needs.

\subsubsection{Relationship Management}

Relationship management encompasses social interactions. It has been defined as the ability to use awareness of one's emotions as well as the emotions of others to manage interactions successfully, which includes clear communication as well as effective conflict management (Lam \& O'Higgins, 2012).

Here, the Relationship Management cluster is described by six competencies:

Developing Others: Sensing others' development needs and bolstering their abilities.

Inspirational Leadership: Inspiring and guiding individuals and groups.

Change Catalyst: Initiating or managing change.

Influence: Wielding effective tactics for persuasion. 
Conflict Management: Negotiating and resolving disagreements.

Teamwork and Collaboration: Working with others towards shared goals, creating group synergy in pursuing collective goals.

\subsection{Work Outcomes}

Various studies, have explored the hypotheses that emotional intelligence relates to various job-related outcomes, including job performance (Koman \& Wolff, 2008; Menges \& Bruch, 2009; Adeoye \& Emeke, 2010), work attitudes and outcomes such as job satisfaction, job involvement, career commitment and organizational commitment (Carmeli, 2003; Salami, 2008; Adeoyo \& Torubelli, 2011; Lam \& O'Higgins 2012; Kanten, 2014), leadership success (Palmer, et al., 2001; Gardner \& Stough, 2002) and citizenship behaviors (Day \& Carroll, 2004). While multiple studies have probed into EI relationships and correlations, it is perhaps safe to conclude that the most explored territory among the previously mentioned is the EI and leadership correlation. In addition, research found that emotional intelligence is positively related to problem solving strategies and negatively related to bargaining strategies in conflict management (Rahim et al., 2002).

Not only do researchers state that there are close relationships between human capital competencies (e.g. personality, knowledge, skills, ability, relationships, emotional intelligence, etc.) and work-related employees' attitudes and behaviors (e.g. commitment to customer service, job performance, job satisfaction, motivation, employee turnover, organizational commitment, etc.) (Basoda, 2014), but the effect of employees' emotional capabilities extend to reach customer-related outcomes (e.g. customer value, customer satisfaction, service quality) and organizational-related outcomes (e.g., competitive advantage, profitability, productivity, positive word-of-mouth, etc.) in service settings (Abdallah \& Phan, 2007; Kusluvan et al., 2010; Obeidate et al., 2014).

In the next subsections, the authors explore what previous literature have revealed about the relationship between EI and the specific work-related attitudes of Job Satisfaction, Organizational Commitment and Customer Service Behavior.

\subsubsection{Job Satisfaction}

Defined as an individual's cognitive, affective and evaluative reactions towards their job (Greenberg \& Baron, 1993), or put in simpler terms how negative or positive employees feel about their work (Spector \& Fox, 2003). Job Satisfaction is among the most essential work-related attitudes managers, who believe that an organization has a responsibility to provide employees with jobs that are challenging and intrinsically rewarding, should seek to attain in their workplace (Robbins, 2001). Job satisfaction can also be viewed as a function of satisfaction or dissatisfaction with respect to different aspects of the job (pay, supervision, the work itself, the work itself, pay, promotions, recognition, working conditions, benefits andquality of relations with supervision and co-workers (Organ \& Bateman, 1991; Hart \& Williower, 2001).

Though job satisfaction is seen as a set of complex emotional reactions to the job (Locke, 1969), many have attempted to study and explore the factors that lead to job satisfaction and many have found that job satisfaction is positively associated with the construct of emotional intelligence (such as Smith et al., 1969). A more recent example of this is Brunetto et al. (2012) who studied the effect of EI upon the job satisfaction of police officers in Australia. Results of their studies also pointed out that EI led to job satisfaction which, as a result, led to employees' engagement and organizational commitment. Sy et al. (2006) and Güleryüz et al. (2008) tested the hypothesis in different settings and came up with the same research findings of the studies.

These findings hold strong implications for the work environment because employees who are characterized as highly satisfied are more time-effective at work, less engaged in absenteeism and lower turnover (Spector, 1994) and better at appraising and regulating their and other's feelings, which in turn positively impact morale and job satisfaction (Sy et al., 2006) and experience less stress at work (Joiner \& Bartram, 2004).

Employees with low EI levels are lacking behind in possessing abilities to understand, regulate and manage their emotions when they are dealing with difficult and complex situations, and, as a result, they adopt unbalanced behaviors exacerbating negative feelings and reducing their job performance levels (Trivellas, 2013).

\subsubsection{Organizational Commitment}

Hart and Willower (2001) defined organizational commitment as an individual's identification and involvement with a particular organization. According to them, organizational commitment is characterized by strong belief in the organization's goals and values, willingness to exert considerable effort on behalf of the organization as well as strong desire to maintain membership in the organization. Landen (2003) states that employees are being asked to identify with the organization in spite of a loss of control in their employment relationship. 
The three sources of organizational commitment conceptualized in Meyer and Allen's (1997) three-component commitment model are considered by Meyer et al. (2002) to dominate research regarding organizational commitment. The three sources of commitment as proposed by the model are; affective commitment which emphasizes attachment to the organization where individuals put all their energy into their work which is not expected of them (Bussing, 2002); normative commitment focuses on an employee's feelings of obligation to stay with an organization and continuance organizational commitment (Meyer \& Allen, 1997) refers to the extent to which employees feel committed to their organizations by virtue of the costs that they feel are associated with leaving (Meyer \& Allen, 1984).

Various studies came to the conclusion that emotional intelligence was positively correlated with organizational commitment (such as Ciarrochi et al., 2001; Carnuelli, 2003; Salami, 2008; Aeoyo \& Torubelli, 2011).

\subsubsection{Customer Service Behavior}

Customer service behavior, according to Kanten (2014), includes employees' willingness to help and benefit customers through understanding their needs and influencing them by providing accurate information. Bellou and Andronikidis (2008) attempted to differentiate between two customer service behaviors; role-prescribed behaviors, which refer to the expected behaviors of organizations from their employees within the scope of formal roles; and extra-role behaviors which refer to the helpful and voluntary behaviors which go beyond employees' formal roles that are neither compulsory nor rewarded in the organizations (Kanten, 2014).

Many prior research studies indicate that employees' personality traits significantly affect their customer service behaviors and are considered predictors of their customers' behaviors and reactions during the service encounter (Kusluvan et al., 2010). Moreover, some studies have been devoted to investigate the relationship between personality traits and customer-oriented behavior and concluded that customer-oriented behavior is essential in fulfilling customers' needs and interests by delivering proper solutions (Johari \& Hee, 2013).

In particular, research indicates that emotions play an important role in service encounters (Menon \& Dube 2000). Barlow and Maul (2000) argued for the potential link between EI and customer satisfaction. This is manifested in the reciprocal nature of service encounters that produces an emotional contagious effect whereby customers 'catch' the emotions displayed by the customer service employee (Pugh, 2001). Therefore and yet again, Emotional Intelligence is among the prerequisites that should be sought for in prospective employees. In particular, emotional recognition, empathy and the control and management of negative emotions are considered to be key skills that individuals with high EI possess (Slaski \& Cartwright, 2002).

Furthermore, Catwright and Pappas (2008) have emphasized the economic value in selecting personnel on the basis of their EI. For example, Goleman (1995) claimed that insurance sales agents who scored high on emotional competencies achieved sales figures which were more than twice those of their less emotionally competent peers.

Nevertheless, despite the dedicated studies on this topic, Basoda (2014) argues that a big gap persists to exist in the relevant literature with regards to examining individual traits and customer service behaviors from the aspect of customers and, hence, more investigations should be done in the field of studying EI in service encounters.

\section{Framework and Research Hypotheses}

\subsection{The Relationships between EI and Work Outcomes}

Over a span of decades, empirical research studies have demonstrated positive correlations between job satisfaction and organizational commitment (Yousef, 2000). Furthermore, job satisfaction and organizational commitment are among the antecedents that research has proven to lead to customer service behaviors in organizations (Lee et al., 2006; Lanjananda \& Patterson, 2009).

A decent amount of studies have been dedicated to investigate the relationship between emotional intelligence and work outcomes. For example, VanSickle (2004) found a significant relation between self-awareness and social awareness and coach performances when exploring the performance of softball coaches. Among the researcher's findings only relationship management was significantly related to overall performance. The study also concluded that only the self-awareness cluster showed a significant relationship with job satisfaction. In a similar study, Burrs (2004) conducted a study of 83 mid-level managers from the electronic publishing industry to examine the relationship between emotional competences, measured with the ECI, and follower commitment. A strong positive relationship was found.

Though many recent research in EI emphasized the potential link between EI and customer satisfaction (Cartwright \& Pappas, 2000) coming to a conclusion that emotional recognition, empathy and the control and 
emotion management are key skills that can create a positive organizational climate for service (Slaski \& Cartwright, 2002), it is evident that the effect of a manager's EI on employees' customer service behaviors has been, thus far, an unexplored territory in research.

This is where this research comes in use employing the Emotional Competence Inventory scale (ECI) to measure the effect of a manager's emotional intelligence on an employee's work outcomes of job satisfaction, organizational commitment, and customer service behavior. After a thorough literature review, the resultant research model framework is proposed in Figure 1.

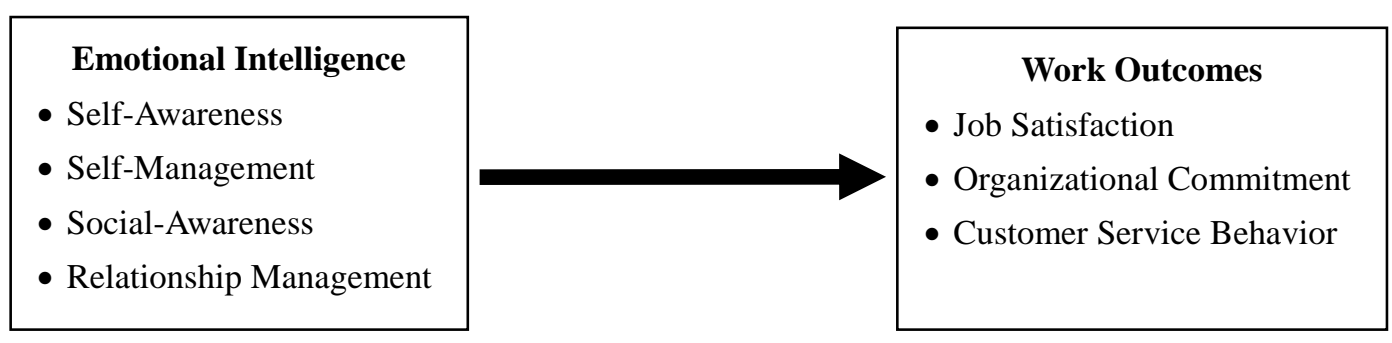

Figure 1. Research model

\subsection{Research Hypotheses}

Based on the previous literature review and theoretical background, the following hypotheses will be addressed:

H0.1: There is no statistically significant relationship between a manager's emotional intelligence and an employee's work outcomes of (job satisfaction, organizational commitment and customer service behaviors).

H0.1.1: There is no statistically significant relationship between a manager's emotional intelligence and an employee's job satisfaction.

H0.1.1.1: There is no statistically significant relationship between self-awareness and job satisfaction.

H0.1.1.2: There is no statistically significant relationship between self-management and job satisfaction.

H0.1.1.3: There is no statistically significant relationship between social awareness and job satisfaction.

H0.1.1.4: There is no statistically significant relationship between relationship management and job satisfaction.

H0.1.2: There is no statistically significant relationship between a manager's emotional intelligence and an employee's organizational commitment.

H0.1.2.1: There is no statistically significant relationship between self-awareness and organizational commitment.

H0.1.2.2: There is no statistically significant relationship between self-management and organizational commitment.

H0.1.2.3: There is no statistically significant relationship between social awareness and organizational commitment.

H0.1.2.4: There is no statistically significant relationship between relationship management and organizational commitment.

H0.1.3: There is no statistically significant relationship between a manager's emotional intelligence and an employee's customer service behaviors.

H0.1.3.1: There is no statistically significant relationship between self-awareness and customer service behaviors.

H0.1.3.2: There is no statistically significant relationship between self-management and customer service behaviors.

H0.1.3.3: There is no statistically significant relationship between social awareness and customer service behaviors.

H0.1.3.4: There is no statistically significant relationship between relationship management and customer service behaviors. 


\section{Methodology}

\subsection{Population and Sample}

The research population for this study represented all 28 insurance companies operating in Jordan. The authors contacted all the companies personally in order to get their permission to participate in the study. Fifteen companies agreed to participate while thirteen declined. Unit of analysis for the research is senior and junior employees as well as supervisors. Simple Random sampling technique was used to choose respondents from each insurance company. A total of three hundred questionnaires were distributed by hand. A small number of respondents filled out the questionnaires in our presence, while majority of respondents promised to fill out their questionnaires in few days. Finally, we received two hundred and two questionnaires. Nine questionnaires were defined as unusable and were excluded from further analysis. The final number of usable questionnaires was one hundred and ninety three representing a response rate of $64.3 \%$.

\subsection{Measurement Analysis}

The measurement scales for this study were adopted from the literature. As discussed in the literature review section, the ECI model developed by Boyatzis et al. (2000) was adopted to measure EI dimensions. The ECI model has been widely used and proved to have high validity and reliability. Additionally, it showed desired levels of convergent validity in factor analyses (Goleman et al., 2002). A total of 72 question items were used to measure the four dimesions of EI. Items were represented with Likert's five-points scale: 1 for 'strongly disagree', 2 for 'disagree', 3 for 'neutral', 4 for 'agree' and 5 for 'strongly agree' to indicate respondents' level of emotional intelligence.

As for work outcomes, we adopted a three-item measurement scale developed by Cammann et al. (1983) to measure job satisfaction. To measure organizational commitment, a six-item scale developed by Meyer et al. (1993) was used. And to measure employees' customer service behaviors, we adopted a 10-item measurement scale from Lee et al. (2006). Similarly, a five-point Likert-Scale ranging from $1=$ strongly disagree to $5=$ strongly agree was used.

Although the measurement scales used in this study were tested by several researchers for validity and reliability, it was highly recommended to re-test the scales due to cultural and industry-related differences (Abdallah et al., 2014; Abdallah, 2013). We used principal component factor analysis to assess the construct validity. We ensured that all items within each measurement scale were uni-dimentional with a factor loading greater than 0.40 and eigenvalue greater than 1 (Phan et al., 2011; Al-Abdallah et al., 2014). Thirty eight question items out of the total number of eighty nine items did not meet our criteria and were excluded from further analysis. This provides additional evidence for the necessity to re-test adopted measurement scales in the empirical studies.

Cronbach's $\alpha$-coefficient was used to evaluate the reliability of the measurement scales. Six scales out of seven met the recommended rule-of-thumb standard of $\alpha \geq 0.70$ implying strong internal consistency (Nunnally, 1978). Alpha coefficient for job satisfaction scale was 0.611 . This level of alpha is accepted for newly developed scales as well as for existing scales used in a new culture for the first time (Nunnally, 1978; Churchill \& Peter, 1984). Finally, we computed the average of emotional intelligence dimensions to represent emotional intelligence overall scale. Validity and reliability analysis were also carried out for the EI overall scale as reported in Table 1. We also computed skewness values for all the constructs and they ranged between -0.797 and 0.067 indicating that our data is normally distributed. Table 1 below provides summary of statistics of our constructs.

Table 1. Summary of statistics of study variables

\begin{tabular}{|c|c|c|c|c|c|c|c|}
\hline variables & Mean & $\begin{array}{l}\text { Standard } \\
\text { deviation }\end{array}$ & $\begin{array}{l}\text { No. of } \\
\text { items }\end{array}$ & $\begin{array}{c}\text { Cronbach's } \\
\text { Alpha }\end{array}$ & (Eigenvalue) & $\begin{array}{c}(\% \text { of } \\
\text { variance) }\end{array}$ & Skewness \\
\hline 1. Self Awareness & 3.50 & 0.769 & 7 & 0.887 & 4.245 & $60.63 \%$ & -0.797 \\
\hline 2. Self Management & 3.52 & 0.602 & 9 & 0.888 & 4.920 & $54.66 \%$ & -0.022 \\
\hline 3. Social Awareness & 3.48 & 0.654 & 8 & 0.879 & 4.374 & $54.68 \%$ & -0.175 \\
\hline 4. Relationship Management & 3.48 & 0.666 & 11 & 0.922 & 6.244 & $56.76 \%$ & -0.399 \\
\hline 5. Emotional Intelligence & 3.49 & 0.593 & 4 & 0.900 & 3.116 & $77.88 \%$ & -0.336 \\
\hline 6. Job Satisfaction & 3.19 & 0.652 & 4 & 0.611 & 1.865 & $46.62 \%$ & -0.103 \\
\hline 7. Organizational Commitment & 3.11 & 0.743 & 3 & 0.792 & 2.147 & $71.55 \%$ & 0.067 \\
\hline 8. Customer service behavior & 3.77 & 0.608 & 6 & 0.890 & 3.933 & $65.54 \%$ & -0.135 \\
\hline
\end{tabular}




\section{Results}

Our initial intention was to use multiple regression analysis to test our hypotheses. We tested the assumptions related to regression analysis concerning normality, linearity, independent error terms, and homoscedasticity, and all the assumptions were met. Next, we proceeded to check our data for multicollinearity. Multicollinearity is a serious problem in multiple regression analysis that may occur when independent variables are highly correlated. Multicollinearity makes identifying the effect of each independent variable difficult due to inability of separating the contributions of individual variables (Hair et al., 1998). We assessed multicollinearity using bivariate correlation and variance inflation factor (VIF). The correlation matrix in Table 2 shows that the independent variables are highly correlated (0.604-0.786). Hair et al. (1998) suggested that even low correlations of 0.30 lead to multicollinearity. Variance inflation factor (VIF) measures the effect of collinearity among the independent variables in multiple regression. We checked the values of VIF and they ranged between 2.133 and 3.352. Allison (1999) asserted that VIF values above 2.5 indicate the existence of muliticollinearity. Therefore, we decided to avoid multiple regression and, instead, use simple regression analysis to ensure that our results were not affected by muliticollinearity.

Table 2. Correlations among independent variables

\begin{tabular}{lcccc}
\hline variables & 1 & 2 & 3 & 4 \\
\hline 1. Self Awareness & 1 & & & \\
2. Self Management & $0.643^{* * *}$ & 1 & & \\
3. Social Awareness & $0.604^{* * *}$ & $0.778^{* * *}$ & 1 & \\
4. Relationship Management & $0.699^{* * *}$ & $0.715^{* * *}$ & $0.786^{* * *}$ & 1 \\
\hline
\end{tabular}

$* * * \mathrm{P} \leq 0.01$

We started hypotheses testing with hypothesis H0.1.1 which indicated that a manager's emotional intelligence is not related to an employee's job satisfaction. We used five separate regression models to test the hypothesis. In the first four models, we entered one dimension at the time of emotional intelligence dimensions. In the fifth model, we entered the emotional intelligence overall scale. The results in Table 3 show that all emotional intelligence dimensions as well as emotional intelligence overall scale were positively and significantly related to job satisfaction ( $\mathrm{P}<0.01$ for all models). Therefore, the null hypothesis H0.1.1 and its sub-hypotheses were rejected.

Table 3. Simple regression of individual EI practices on job satisfaction

\begin{tabular}{|c|c|c|c|c|c|}
\hline Variables & Model 1 & Model 2 & Model 3 & Model 4 & Model 5 \\
\hline (Constant) & $2.026^{* * *}$ & $1.687 * * *$ & $1.831 * * *$ & $2.069^{* * *}$ & $1.541 * * *$ \\
\hline Self awareness & $0.394 * * *$ & & & & \\
\hline Self Management & & $0.396 * * *$ & & & \\
\hline Social awareness & & & $0.394 * * *$ & & \\
\hline Relationship Management & & & & $0.331 * * *$ & \\
\hline Emotional intelligence & & & & & $0.430 * * *$ \\
\hline $\mathrm{R}^{2}$ & 0.155 & 0.157 & 0.155 & 0.110 & 0.185 \\
\hline Adj. $R^{2}$ & 0.151 & 0.152 & 0.151 & 0.105 & 0.181 \\
\hline $\mathrm{F}$ & $35.159 * * *$ & $35.498 * * *$ & $35.100 * * *$ & $23.543 * * *$ & $43.433 * * *$ \\
\hline
\end{tabular}

$* * * \mathrm{P} \leq 0.01$.

Next, we tested hypothesis H0.1.2 which indicated that a manager's emotional intelligence is not related to an employee's organizational commitment. In a similar manner to previous hypothesis, we used five separate regression models. The results in Table 4 show that all emotional intelligence dimensions as well as emotional intelligence overall scale were positively and significantly related to employee's organizational commitment $(\mathrm{P}<$ 0.01 for all models). Therefore, the null hypothesis H0.1.2 and its sub-hypotheses were rejected. 
Table 4. Simple regression of individual EI practices on organizational commitment

\begin{tabular}{clllll}
\hline Variables & Model 1 & Model 2 & Model 3 & Model 4 & Model 5 \\
\hline (Constant) & $2.195^{* * *}$ & $1.674^{* * *}$ & $1.625^{* * *}$ & $1.984^{* * * *}$ & $1.543^{* * *}$ \\
Self awareness & $0.272^{* * *}$ & & & & \\
Self Management & & $0.332^{* * *}$ & & & \\
Social awareness & & & $0.377^{* * *}$ & & $0.292^{* * *}$ \\
Relationship Management & & & & $0.359^{* * *}$ \\
Emotional intelligence & & & & 0.142 \\
$\mathrm{R}^{2}$ & 0.074 & 0.110 & 0.138 & 0.080 & 0.124 \\
Adj. $\mathrm{R}^{2}$ & 0.069 & 0.105 & $31.726^{* * *}$ & $17.752^{* * *}$ & $28.230^{* * *}$ \\
$\mathrm{~F}$ & $15.306^{* * *}$ & $23.620^{* * *}$ & & & \\
\hline
\end{tabular}

$* * * \mathrm{P} \leq 0.01$.

Finally, we tested hypothesis H0.1.3 which indicated that a manager's emotional intelligence is not related to an employee's customer service behaviors. Similar to previous hypotheses, we used five separate regression models. The results in Table 5 show that all emotional intelligence dimensions as well as emotional intelligence overall scale were positively and significantly related to employee's customer service behaviors ( $\mathrm{P}<0.01$ for all models). Therefore, the null hypothesis H0.1.3 and its sub-hypotheses were rejected.

Table 5. Simple regression of individual EI practices on customer service behavior

\begin{tabular}{|c|c|c|c|c|c|}
\hline Variables & Model 1 & Model 2 & Model 3 & Model 4 & Model 5 \\
\hline (Constant) & $3.025^{* * *}$ & $2.329 * * *$ & $2.889 * * *$ & $2.728 * * *$ & $2.486^{* * *}$ \\
\hline Self awareness & $0.269 * * *$ & & & & \\
\hline Self Management & & $0.405 * * *$ & & & \\
\hline Social awareness & & & $0.273^{* * *}$ & & \\
\hline Relationship Management & & & & $0.328 * * *$ & \\
\hline Emotional intelligence & & & & & $0.358 * * *$ \\
\hline $\mathrm{R}^{2}$ & 0.073 & 0.164 & 0.074 & 0.108 & 0.128 \\
\hline Adj. $R^{2}$ & 0.068 & 0.160 & 0.069 & 0.103 & 0.123 \\
\hline $\mathrm{F}$ & $14.942 * * *$ & $37.504 * * *$ & $15.330 * * *$ & $23.060 * * *$ & $28.050 * * *$ \\
\hline
\end{tabular}

\section{Discussion and Conclusions}

In this paper, we empirically investigated the effect of a manager's emotional intelligence (in terms of self-awareness, self-management, social awareness, and relationship management) on employees' work outcomes (in terms of job satisfaction, organizational commitment, and customer service behavior) in the insurance industry in Jordan. The results in the previous section show that all EI dimensions positively affect the three work outcomes considered in our study. Conducting such research in a developing Middle Eastern country such as Jordan is an attempt to broaden the conceptualization of emotional intelligence and shed light on the concept of EI in a third-world country. Additionally, most research on emotional intelligence in the workplace has concentrated on its contribution to leadership behaviors (George, 2000) rather than its effect on the larger employee population and their work outcomes (Meisler \& Vigoda, 2014). The small number that actually examined the effect of EI on behavioral and attitudinal outcomes minimized its use as a tool for personnel planning and development (Sy et al., 2006; Davar \& Singh, 2014). Therefore, this research contributed to the literature by focusing on the contribution of EI to shaping employees' work attitudes and outcomes, which is an area where there has been a lack of research (Law, et al., 2008).

Our results are consistent with the results of some previous studies that found positive relationship between EI and some dimensions of work outcomes (e.g. Brunetto et al., 2012; Adeoyo \& Torubelli, 2011; Güleryüz et al., 2008; Salami, 2008; Sy et al., 2006). The results also supported the findings of Webb (2014) who concluded that employees who are supervised by managers with EI seem to exhibit above average positive attitudes and efforts.

The findings demonstrated that emotions are among the main pillars that influence employees' behaviors and outcomes in service companies. In an era characterized by intensive focus on quality and productivity 
improvements, the vital contribution of EI to foster employees' attitudes should not be overlooked. Today's high competitive environment requires managers in developing countries to shift their traditional behavior of intimidating employees, relying on high unemployment rates and scarcity of jobs, to a behavior that creates a sense of belonging for employees. EI is the ideal ingredient which enables managers to inspire employees, leading them to become satisfied and motivated. This is in accordance with affective events theory (Weiss \& Cropanzano, 1996) which proposed that emotional experiences at the work-place influence employees' short and long-term attitudes and behaviors.

It should be noted that EI is not restricted to managers. Employees' relationships play a significant role in generating and diffusing a healthy environment that enhances job satisfaction and commitment. Employees with high levels of EI are not only expected to control and adjust their emotions, but also to grasp the emotions of their peers. Such employees are usually more satisfied with their jobs because they are more skillful at appraising, regulating and directing their own emotions in contrast to those with a lower overall EI (Trivellas et al., 2013).

Service organizations have a real challenge to retain existing customers and attract new customers. Customers nowadays are more complex with convoluted requirements and needs. The results of this study demonstrate that EI positively affect customer service behavior. Employees with high levels of EI are more capable of controlling and adapting their intrapersonal and interpersonal emotions and predicting emotional state of the customers, and thus, being more responsive to different customer moods, whims and behaviors.

All in all, service organizations have to pay a considerable attention to the process of selecting managers and employees so that they consider EI traits amongst the main prerequisites for prospective recruitment and promotion. EI should be considered by service organizations as a strategic tool for personnel planning, training and development. Moreover, employee satisfaction, commitment, and customer service behavior are expected to facilitate the adoption of innovative strategies such as customer-value strategy and customer-centric strategy. Yet, empirical studies are needed in the service industry to confirm this expected relationship.

The limitation of our study is that we only selected the insurance industry. Although the selection of one industry facilitated our focus and the process of data collection, it limits the generalizability of the results to other service industries. Furthermore, we have had to delete about half of the question items adopted from Emotional Competence Inventory model (ECI) in order to get valid and reliable measures of EI dimensions. Despite the fact that we used the model in new cultural and industrial settings, model transferability may be questionable.

Further studies are needed to investigate the effect of EI on employees' work outcomes in other service industries as well as in manufacturing companies. Also, the direct and indirect linkages between EI and different types of innovation have to be investigated in developed and developing countries.

\section{References}

Abdallah, A. B. (2013). The Influence of "Soft" and "Hard" Total Quality Management (TQM) Practices on Total Productive Maintenance (TPM) in Jordanian Manufacturing Companies. International Journal of Business and Management, 8(21), 1-13. http://dx.doi.org/10.5539/ijbm.v8n21p1

Abdallah, A. B., Obeidat, B. Y., \& Aqqad, N. O. (2014). The Impact of Supply Chain Management Practices on Supply Chain Performance in Jordan: The Moderating Effect of Competitive Intensity. International Business Research, 7(3), 13-27. http://dx.doi.org/10.5539/ibr.v7n3p13

Abdallah, A., \& Phan, C. A. (2007). The Relationship between Just-In-Time Production and Human Resource Management, and Their Impact on Competitive Performance.Yokohama Business Review, 28(2), 27-57.

Adeoye, H., \& Emeke, E. (2010). Emotional Intelligence and Self-Efficacy as Determinants of Academic

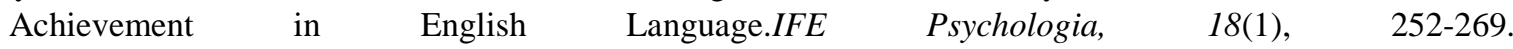
http://dx.doi.org/10.4314/ifep.v18i1.51663

Adeoyo, H., \& Torubelli, V. (2011). Emotional Intelligence and Human Relationship Management as Predictors $\begin{array}{llll}\text { of Organisational Commitment. IFE PsychologIA, 19(2), 212-226. } & \text {. }\end{array}$ http://dx.doi.org/10.4314/ifep.v19i2.69532

Al-Abdallah, G. M., Abdallah, A. B., \& BanyHamdan, K. (2014). The Impact of Supplier Relationship Management on Competitive Performance of Manufacturing Firms.International Journal of Business and Management, 9(2), 192-202. http://dx.doi.org/10.5539/ijbm.v9n2p192

Alawneh, A. (2013). The Relationship between the Emotional Intelligence Level and The Effectiveness of AProject Manager (Unpublished master's thesis). The University of Jordan, Jordan. 
Allison, P. D. (1999). Multiple Regression: Primer. CA: Thousand Oaks, Pine Forge Press.

Barbalet, J. (2004). Consciousness, Emotions and Science: Theory and Research on Human Emotions (Advances in Group Processes). Emerald Group Publishing Limited, 21, 255-272.

Bar-On, R. (1997). The Emotional Quotient Inventory (EQ-I): Technical Manual. Toronto: Multi-Health Systems.

Barlow, J., \& Maul, D. (2000). Emotional value: Creating strong bonds with your customers. Berrett-Koehler, San Francisco.

Basoda, A. (2014). Exploring Hotel Employees' Individual and Work-Related Outcomes from the Aspect of Customer online Reviews: A Qualitative Approach. 13th International Academic Conference, IISES, Antibes, pp. 42-52.

Bellou, V., \& Andronikidis, A. (2008). The Impact of Internal Service Quality on Customer Service Behavior: Evidence from the Banking Sector. International Journal of Quality \& Reliability Management, 25(9), 943-954. http://dx.doi.org/10.1108/02656710810908098

Boyatzis, E. (1982). The Competent Manager: A Model for Effective Performance. John Wiley and Sons.

Boyatzis, E., \& Sala, F. (2004). Assessing Emotional Intelligence Competencies: The Measurement of Emotional Intelligence. Hauppauge, NY: Novas Science Publishers.

Boyatzis, E., Goleman, D., \& Rhee, K. (2000). Clustering competence in emotional intelligence: Insights from the Emotional Competence Inventory (ECI). Handbook Of Emotional Intelligence, 343-362.

Brunetto, Y., Teo, S., Shacklock, K., \& Wharton R. (2012). Emotional intelligence, job satisfaction, well-being and engagement: explaining organizational commitment and turnover intentions in policing. Human Resource Management Journal, 2(4), 428-441. http://dx.doi.org/10.1111/j.1748-8583.2012.00198.x

Burrs, L. J. (2004). The relationship between the mid-level leader's emotional competence and follower commitment (Unpublished Dissertation). University of Phoenix, USA.

Bussing, A. (2002). Trust and its relations to commitment and involvement in work and organizations. South African Journal of Industrial Psychology, 28(4), 36-42.

Cammann, C., Fichman, M., Jenkins, Jr, G., \& Klesh, J. R. (1983). Assessing the attitudes and perceptions of organizational members. In S. E. Seashore, E. E. Lawler, P. H. Mirvis, \& C. Cammann (Eds.), Assessing Organizational Change. New York: John Wiley and Sons.

Carmeli, A., Yitzhak-Halevy, M., \& Weisberg, J. (2009). The relationship between emotional intelligence and psychological wellbeing. Journal of Managerial Psychology, 24(1), 66-78. http://dx.doi.org/10.1108/02683940910922546

Carmeli, A. (2003). The relationship between emotional intelligence and work attitudes, behavior and outcomes: An examination among senior managers. Journal of Managerial Psychology, 18(8), 788-813. http://dx.doi.org/10.1108/02683940310511881

Carnuelli, A. (2003). The Relationship between Emotional Intelligence and Work Attitudes Behavior and Outcomes: An Examination among Senior Managers. Journal of Management Psychology, 18(8), 788-813. http://dx.doi.org/10.1108/02683940310511881

Cartwright, S., \& Pappas, C. (2008). Emotional intelligence, its measurement and implications for the workplace. $\begin{array}{lllll}\text { International Journal of } & \text { Management }\end{array}$ http://dx.doi.org/10.1111/j.1468-2370.2007.00220.x

Caruso, R., Mayer, D., \& Salovey, P. (2002). Relation of a measure of emotional intelligence to personality. Journal of Personality Assessment, 79(2), 306-320. http://dx.doi.org/10.1207/S15327752JPA7902_12

Churchill, G. A., \& Peter, J. P. (1984). Research Design Effects on the Reliability of Rating Scales: A Meta-Analysis. Journal of Marketing Research, 21(4), 360-375. http://dx.doi.org/10.2307/3151463

Ciarrochi, J., Chan, C., \& Caputi, P. (2001). A Critical Evaluation of the Emotional Intelligence Construct. Personality and Individual Differences, 28(3), 539-561. http://dx.doi.org/10.1016/S0191-8869(99)00119-1

Damasio, A. (1994). Descartes' error: Emotions, reason, and the human brain. New York: Avon Books.

Davar, S. C., \& Singh, N. (2014). Emotional Intelligence \& Job Performance in Banking \& Insurance Sector in India. The Indian Journal of Industrial Relations, 49(4), 722-733. 
Day, L., \& Carroll, A. (2004). Using an ability-based measure of EI to predict subordinate's performance, group performance, and group citizenship behaviours. Personality and Individual Differences, 36(6), 1443-1458. http://dx.doi.org/10.1016/S0191-8869(03)00240-X

De Sousa, R. (1987). The Rationality of Emotion. Cambridge, MA: MIT Press.

Dulewicz, V., \& Higgs, M. (2000). Emotional intelligence: A review and evaluation study. Journal of Managerial Psychology, 15(4), 341-372. http://dx.doi.org/10.1016/S0191-8869(03)00240-X

Early, P. C., \& Ang, S. (2003). Cultural Intelligence: Individual Interactions Across Cultures. California: Stanford Press.

Fineman, S. (2000). Emotions in Organizations. London: Sage.

Gardner, H. (1983). Frames of Mind. New York: Basic Books.

Gardner, L., \& Stough, C. (2002). Examining the relationship between leadership and emotional intelligence in senior level managers. Leadership \& Organization Development Journal, 23(2), 68-78. http://dx.doi.org/10.1108/01437730210419198

George, J. M. (2000). Emotions and leadership: The role of emotional intelligence. Human Relations, 53(8), 1027-1055. http://dx.doi.org/ 10.1177/0018726700538001

Goleman, D. (1995). EmotionalIntelligence: Why It Can Matter More than IQ. New York: Bantam Books.

Goleman, D. (1998). Working with Emotional Intelligence. New York, NY: Bantam Books.

Goleman, D., Boyatzis, R., \& McKee, A. (2002). Primal Leadership: Realizing the Power of Emotional Intelligence. Boston, MA: Harvard Business School Press.

Greenberg, J., \& Baron, A. (1993). Behavior in organizations: Understanding and managing the human side of work (4th ed.). Columbus, OH: Merril.

Güleryüz, G., Güney, S., Aydın, M., \& Assan, Ö. (2008). The mediating effect of job satisfaction between emotional intelligence and organizational commitment of nurses: A questionnaire survey. International Journal of Nursing Studies, 45(11), 162-1635. http://dx.doi.org/10.1016/j.ijnurstu.2008.02.004

Hair, J., Anderson, T., \& Black, W. (1998). Multivariate Data Analysis (5th ed.). Prentice-Hall, Inc., NJ.

Hart, D., \& Willower, D. (2001). Principals' Organizational Commitment and School Environmental Robustness. Journal of Educational Research, 87(3), 174-179. http://dx.doi.org/ 10.1080/00220671.1994.9941239

Hedlund, J., \& Sternberg, J. (2000). Two many intelligences?Integrating social, emotional, and practical intelligence. The Handbook of Emotional Intelligence: Theory, Development, Assessment, and Application at Home, School and in the Workplace. New York, NY: Jossey-Bass/Wiley.

Heizer, J., Render, P., \& Zu'bi, Z. (2013). Operation Management (Arab World Edition). Pearson Education LTD, England.

Johari, H., \& Hee, C. (2013). Personality traits and customer-oriented behaviour in the health tourism hospitals in Malaysia. International Journal of Trade Economics and Finance, 4(4), 213-216. http://dx.doi.org/0.7763/IJTEF.2013.V4.288

Joiner, T., \& Bartram, T. (2004). How empowerment and social support affect Australian nurses' work stressors. Australian Health Review, 28(1), 56-64. http://webstat.latrobe.edu.au/url/dx.doi.org/10.1071/AH040056

Jordan, J., Ashkanasy, M., Hartel, J., \& Hooper, S. (2002). Workgroup emotional intelligence, scale development and relationship to team process effectiveness and goal focus. Human Resource Management Review, 12(2), 195-214. http://dx.doi.org/ 10.1016S1053-4822(2)00046-3

Kanten, P. (2014). The effect of cultural intelligence on career competencies and customer-oriented service behaviors. Istanbul University Journal of the School of Business, 43(1), 100-119.

Kerr, R., Garvin, J., Heaton N., \& Boyle, E. (2006). Emotional intelligence and leadership effectiveness. Development Journal, 27(4), 265-279. http://dx.doi.org/10.1108/01437730610666028

Koman, E., \& Wolff, S. (2008). Emotional intelligence competencies in the team and team leader: A multi-level examination of the impact of emotional intelligence on team performance. Journal of Management Development, 27(1), 55-75. http://dx.doi.org/10.1108/02621710810840767

Kusluvan, S., Kusluvan, Z., Ilhan, İ., \& Buyruk, L. (2010). The human dimension: A review of human resources management issues in the tourism and hospitality industry. Cornell Hospitality Quarterly, 51(2), 171-214. 
http://dx.doi.org/10.1177/1938965510362871

Lam, C., \& O'Higgins, E. (2012). Enhancing employee outcomes: The interrelated influences of managers 'emotional intelligence and leadership style. Leadership \& Organization Development Journal, 33(2). 149-174. http://dx.doi.org/10.1108/01437731211203465

Landen, M. (2003). Citizenship or careerism: Perceptions and impressions of goodness. Department of Economics and Human Resource Management, Leeds Business School, UK.

Lanjananda, P., \& Patterson, G. (2009). Determinants of customer-oriented behaviour in a health care context. Journal of Service Management, 20(1), 5-32. http://dx.doi.org/10.1108/09564230910936832

Law, K. S., Wong, C., Huang, G., \& Li, X. (2008). The effects of emotional intelligence on job performance and life satisfaction for the research and development scientists in China. Asia Pacific Journal of Management, 25(1), 51-69. http://dx.doi.org/10.1007/s10490-007-9062-3

Lee, K., Nam, H., Park, H., \& Lee, A. (2006). What Factors Influence Customer-Oriented Prosocial Behavior of Customer-Contact Employees? Journal of Services Marketing. 20(4), 251-264. http://dx.doi.org/10.1108/08876040610674599

LeDoux, J. (2003). The Emotional Brain, Fear, and the Amygdala. Cellular and Molecular Neurobiology, 23(415), 727-738.http://dx.doi.org/10.1023/A:1025048802629

Locke, A. (1969). What is job satisfaction? Organizational Behaviour and Human Performance, 4(4), 309-336. http://dx.doi.org/10.1016/0030-5073(69)90013-0

Maini.J., Singh, B., \& Kaur, P. (2012). The Relationship among Emotional Intelligence and Outcome Variables. The Journal of Business Perspective, 16(3), 187-199. http://dx.doi.org/10.1177/0972262912460155

Martin, J., Kuopoff, K., \& Beckman, C. (1998). An Alternative to Bureaucratic Impersonality and Emotional Labour. Bounded Emotional at the Body Shop .Administrative Science Quarterly, 43(2), 429-469. http://dx.doi.org/10.2307/2393858

Mayer, D., Caruso, R., \& Salovey, P. (1999). Emotional intelligence meets traditional standards for an intelligence. Intelligence, 27(4), 267-298. http://dx.doi.org/10.1016/S0160-2896(99)00016-1

Mayer, D., Caruso, R., \& Salovey, P. (2000). The Handbook of Emotional Intelligence: Theory, Development, Assessment, and Application at Home, School and in the Workplace. New York, NY: Jossey-Bass/Wiley.

McCleskey, J. (2014). Emotional intelligence and leadership: A review of the progress, controversy, and criticism. $\begin{array}{lllll}\text { International Journal of } & \text { Organizational }\end{array}$ http://dx.doi.org/10.1108/IJOA-03-2012-0568

Meisler, G., \& Vigoda-Gadot, E. (2014). Perceived organizational politics, emotional intelligence and work outcomes, Empirical exploration of direct and indirect effects. Personnel Review, 43(1), 116-135. http://dx.doi.org/10.1108/PR-02-2012-0040

Menges, J., \& Bruch, H. (2009). Organizational emotional intelligence and performance: An empirical study. Book Series: Research on Emotion in Organizations, 181-209. Emerald Group Publishing Limited.

Menon, K., \& Dube, L. (2000).Ensuring Greater Satisfaction by Engineering Sales Person Response to Customer Emotions. Journal of Retailing, 76(3), 285-307. http://dx.doi.org/10.1016/S0022-4359(00)00034-8

Meyer, P., \& Allen, J. (1984). Testing the 'side-bet theory' of organizational commitment: Some methodological $\begin{array}{lllll}\text { considerations. Journal of } & \text { Applied }\end{array}$ http://dx.doi.org/10.1037/0021-9010.69.3.372

Meyer, P., \& Allen, J. (1997).Commitment in the Workplace: Theory, Research and Application. CA: Sage Publications/ATOB.

Meyer, J., Allen, N., \& Smith, C. (1993). Commitment to Organizations and Occupations: Extension and Test of a Three-component Conceptualization. Journal of Applied Psychology, 78(4), 538-551. http://dx.doi.org/10.1037/0021-9010.78.4.538

Meyer, J. P., Stanley, D. J., Herscovitch, L., \& Topolnytsky, L. (2002). Affective, Continuance and Normative Commitment to the Organization: A Meta-analysis of Antecedents, Correlates, and Consequences. Journal of Vocational Behavior, 61(1), 20-52. http://dx.doi.org/10.1006/jvbe.2001.1842

Mingkai, J. C., \& Oluremi, B. A. (2012). Conflict and trust: The mediating effects of emotional arousal and self-conscious emotions. International Journal of Conflict Management, 23(1), 19-56. 
http://dx.doi.org/10.1108/10444061211199313

Nunnally, J. (1978). Psychometric Theory (2nd ed.). NY: McGraw-Hill.

Obeidat, B. Y., Masa'deh, R. M., \& Abdallah, A. B. (2014). The Relationships among Human Resource Management Practices, Organizational Commitment, and Knowledge Management Processes: A Structural Equation Modeling Approach. International Journal of Business and Management, 9(3), 9-26. http://dx.doi.org/10.5539/ijbm.v9n3p9

Organ, D. W., \& Bateman, T. S. (1991). Organizational Behavior (4th ed.). Homewood: Irwin.

Palmer, B., Walls, M., Burgess, Z., \& Stough, C. (2001). Emotional intelligence and effective leadership. Leadership \& Organization Development Journal, 22(1), 5-10. http://dx.doi.org/10.1108/01437730110380174

Phan, A. C., Abdallah, A. B., \& Matsui, Y. (2011). Quality Management Practices and Competitive Performance: Empirical Evidence from Japanese Manufacturing Companies. International Journal of Production Economics, 133(2), 518-529. http://dx.doi.org/10.1016/j.ijpe.2011.01.024

Pugh, D. (2001). Service with a smile: Emotional contagion in the service encounter. Academy of Management Journal. 44(5), 1018-1028. http://dx.doi.org/10.2307/3069445

Rahim, A., Zhao, H., Yu, S., Chan, W., Kwok, Y., Alves, G., Lee, W., Rahman, S., Ferdausy, S., \& Rene, W. (2002). A model of EI and conflict management strategies: a study in seven countries. The International Journal of Organisational Analysis, 10(4), 302-326. http://dx.doi.org/10.2139/ssrn.429760

Renae, M. H., \& Michelle, R. T.(2013). Emotional Boundary Management: A New Adaptive Approach to Emotion Regulation at Work. In P. L. Perrewé, C. C. Rosen, J. R. B. Halbesleben (Eds.), The Role of Emotion and Emotion Regulation in Job Stress and Well Being (Research in Occupational Stress and Well-being (Vol. 11, pp. 35-74). Emerald Group Publishing Limited.

Robbins, S. P. (2001). Organizational Behaviour. Upper Saddle River, NJ: Prentice-Hall.

Salami, O. (2008). Demographic and Psychological Factors Predicting Organizational Commitment Among Industrial Workers. Anthropologist, 10(1), 31-38.

Salovey, P., \& Mayer, J. (1990). Emotional intelligence. Imagination, Cognition, and Personality, 9(3), 185-211. http://dx.doi.org/10.2190/DUGG-P24E-52WK-6CDG

Schutte, S., Malouff, M., Hall, E., Haggerty, J., Cooper, T., Golden, J., \& Dornheim, L. (1998). Development and validation of a measure of emotional intelligence. Personality and Individual Differences, 25(2), 167-177. http://dx.doi.org/10.1016/S0191-8869(98)00001-4

Slaski, M., \& Cartwright, S. (2002). Health, performance and emotional intelligence. Stress and Health, 18(2), 63-69. http://dx.doi.org/10.1002/smi.926

Smith, C., Kendall, H., \& Hulin, L. (1969). The Measurement of Satisfaction in Work and Retirement: Strategy for the Study of Attitudes. Rand-McNally Company, Chicago, IL.

Spector, E. (1994). Using self-reported questionnaires in OB research: A comment on the use of a controversial method. Journal of Organizational Behavior, 15(5), 385-392. http://dx.doi.org/10.1002/job.4030150503

Spector, P., \& Fox, S. (2003). Reducing subjectivity in the assessment of the job environment and development of the factual autonomy scale (FAS). Journal of Organizational Behavior, 24(4), 417-432. http://dx.doi.org/10.1002/job.199

Stanley, R. O., \& Burrows, G. D. (2005). The role of stress in mental illness: The practice. London: CRC Press.

Steiner, C. (1984). Emotional literacy. Transactional Analysis Journal, 14(1), 162-173.

Sternberg, R. J. (1996). Successful intelligence: How practical and creative intelligence determine success in life. New York: Simon and Shuster.

Sunindijo, R., \& Hadikusumo, B. (2013). Emotional Intelligence for Managing Conflicts in the Socio-Cultural Norms of the Thai Construction Industry. Journal of Management in Engineering, 30(6), 1943-5479. http://dx.doi.org/10.1061/(ASCE)ME.1943-5479.0000211

Sy, T., Tram, S., \& O'Hara, A. (2006). Relation of employee and manager emotional intelligence to job satisfaction and performance. Journal of Vocational Behavior, 68(3), 461-473. http://dx.doi.org/10.1016/j.jvb.2005.10.003 
Tenhouten, W. (1996). Introduction: Sociology of Emotions. International Journal of Sociology and Social Policy, 16(9/10), 1-20. http://dx.doi.org/10.1108/eb013267

Trivellas, P., Gerogiannisb, V., \& Svarnab, S. (2013). Exploring workplace implications of Emotional Intelligence (WLEIS) in hospitals: Job satisfaction and turnover Intentions. Procedia-Social and Behavioral Sciences, 73(1), 701-709. http://dx.doi.org/10.1016/j.sbspro.2013.02.108

VanSickle, L. (2004). The relationship between emotional intelligence and coaching effectiveness in Division softball coaches (Unpublished Dissertation). College of Education, University of Kentucky, Lexington, KY.

Webb, K. (2014). How Managers' Emotional Intelligence Impacts Employees' Satisfaction and Commitment: A Structural Equation Model. The IUP Journal of Organizational Behavior, 13(2), 7-24. http://dx.doi.org/10.2139/ssrn.2236390

Weiss, M., \& Cropanzano, R. (1996). Affective events theory: A theoretical discussion of the structure, causes and consequences of affective experiences at work. Research in Organizational Behavior, 18, 1-74.

Yousef, A. (2000). Organizational commitment: A mediator of the relationships of leadership behavior with job satisfaction and performance in a non-western country. Journal of Managerial Psychology, 15(1), 6-24. http://dx.doi.org/10.1108/02683940010305270

\section{Copyrights}

Copyright for this article is retained by the author(s), with first publication rights granted to the journal.

This is an open-access article distributed under the terms and conditions of the Creative Commons Attribution license (http://creativecommons.org/licenses/by/3.0/). 